\title{
Effect of formic, acetic and propionic acid on preservation and aerobic deterioration of grass silage
}

\author{
$F$ Driehuis, $P G$ van Wikselaar, AM van Vuuren \\ Institute for Animal Science and Health (ID-DLO), PO Box 160,8200 AD Lelystad. The Netherlands
}

\begin{abstract}
Aerobic deterioration of silage is initiated by yeasts or acetic acid bacteria, which in the presence of $\mathrm{O}_{2}$ oxidize the preserving acids. Deterioration is manifested by a rise in temperature and $\mathrm{pH}$. Volatile fatty acids are recognized as inhibitors of yeast growth. We investigated the effects of formic, acetic and propionic acid on preservation and aerobic deterioration of low dry matter (DM) grass silage. For comparison untreated high DM grass silage was also included in the experiment.
\end{abstract}

Perennial ryegrass (second cut) was wilted to $23 \% \mathrm{DM}$ and $43 \% \mathrm{DM}$. The $23 \% \mathrm{DM}$ grass was chopped and treated with equimolar amounts of formic acid (FA; $3.3 \mathrm{~g} / \mathrm{kg}$ ), acetic acid (AA; $4.3 \mathrm{~g} / \mathrm{kg}$ ) or propionic acid (PA ; 5.3 $\mathrm{g} / \mathrm{kg}$ ) or water (CON). The $43 \%$ DM grass was not chopped (HDM). Portions of $2.3 \mathrm{~kg}$ of grass were ensiled in duplicate in 10 I silos permitting repeated sampling. After 84 days $\mathrm{O}_{2}$ was added to $2.5 \%(\mathrm{v} / \mathrm{v})$ and kept at that level for 6 days. Subsequently, the silages were exposed to air for 10 days.

Ensilage phase. Growth of LAB and lactic acid production were retarded in HDM and FA treated silages but not or only slightly in
$A A$ and $P A$ treated silages. High yeast counts were detected in FA and $A A$ treated silages 6-10 days after ensiling. Thereafter a reduction was observed. Yeast counts in CON and PA silages remained low. In HDM silage a relatively high and constant level yeast was found. A high ethanol content was detected in FA silage. Fermentation losses were highest in FA silage and lowest in AA, PA and HDM silage.

Aerobic phase. Immediately after infusion of $2.5 \% \mathrm{O}_{2}$ a rapid increase of yeast numbers was observed in CON silage. A slower increase was observed in FA and AA silage. No or a slight increase was observed in PA and HDM silage. After exposure to air yeast counts increased at a similar rate in CON, FA and $A A$ silage. Silage $\mathrm{pH}$ started to increase 1.5 days ( $C O N$ ) or 3.5 days ( $F A$ and $A A$ ) after exposure to air. Only a slight increase in yeast numbers and no increase in $\mathrm{pH}$ was observed during 10 days of exposure of PA and HDM silage.

In conclusion, PA and a high DM content showed the highest efficacy with respect to inhibition of aerobic deterioration. Furthermore, in contrast to FA, PA did not retard lactic acid fermentation in the early ensilage phase.

\begin{tabular}{|c|c|c|c|c|c|c|c|c|c|c|}
\hline & \multicolumn{5}{|c|}{6 days after ensiling } & \multicolumn{5}{|c|}{84 days after ensiling } \\
\hline & CON & FA & AA & PA & HDM & CON & FA & $\mathrm{AA}$ & PA & HDM \\
\hline$A B(\log \mathrm{cfu} / \mathrm{g})$ & 8.7 & 7.9 & 8.6 & 8.8 & 8.7 & 8.1 & 6.8 & 8.0 & 7.7 & 7.7 \\
\hline reasts $(\log \mathrm{cfu} / \mathrm{g})$ & $<2$ & 6.4 & 5.3 & 3.1 & 3.8 & $<2$ & 2.9 & $<2$ & $<2$ & 5.0 \\
\hline lactic acid ( $g / \mathrm{kg} \mathrm{DM})$ & 96 & 11 & 78 & 73 & 11 & 122 & 76 & 101 & 102 & 79 \\
\hline acetic acid (g/kg DM) & 25 & 6 & 39 & 22 & 9 & 30 & 10 & 48 & 26 & 18 \\
\hline ethanol ( $\mathrm{g} / \mathrm{kg} \mathrm{DM})$ & 5 & 7 & 4 & 3 & 7 & 7 & 49 & 6 & 4 & 11 \\
\hline \multirow[t]{3}{*}{ weight loss (g/kg DM) } & 31 & 10 & 24 & 24 & 15 & 29 & 55 & 20 & 22 & 23 \\
\hline & \multicolumn{5}{|c|}{6 days exposure to $2.5 \% \mathrm{O}_{2}$} & \multicolumn{5}{|c|}{4 days exposure to $21 \% \mathrm{O}_{2}$} \\
\hline & CON & FA & AA & PA & HDM & CON & $\mathrm{FA}$ & $A A$ & PA & HDM \\
\hline $\begin{array}{l}\text { yeasts (log cfu/g) } \\
\text { pH }\end{array}$ & $\begin{array}{c}6.0 \\
3.96\end{array}$ & $\begin{array}{c}5.2 \\
3.93\end{array}$ & $\begin{array}{c}4.2 \\
3.93\end{array}$ & $\begin{array}{c}<2 \\
3.90\end{array}$ & $\begin{array}{c}5.6 \\
4.29\end{array}$ & $\begin{array}{c}8.8 \\
4.94\end{array}$ & $\begin{array}{c}8.0 \\
4.07\end{array}$ & $\begin{array}{c}8.4 \\
4.12\end{array}$ & $\begin{array}{c}3.7 \\
3.92\end{array}$ & $\begin{array}{c}5.8 \\
4.34\end{array}$ \\
\hline
\end{tabular}

